\title{
Developing Moral Reasoning Theory Based on Islamic Education Perspective
}

\author{
Ainul Yaqin \\ Department of Islamic Education \\ Universitas Islam Majapahit \\ Mojokerto, Indonesia \\ ainulyaqin@unim.ac.id
}

\begin{abstract}
This moral reasoning study presents Islamic education perspective. In this literature study, I tried to present the concept of moral reasoning levels that Kohlberg compiled to be juxtaposed with al-Ghazali and other moslem scholars (ulama), and also examined its congruence, in order to be discovered its similarities and differences. This study will compare that moral reasoning in Ilmu al-Akhlaq had some levels as well as Kohlberg's moral reasoning. The morals' level; Awam, Khawas, Khawas al-khawas which refers to the concept of Tasawuf, the dimension of Islamic teaching, can be juxtaposed with the level of moral reasoning; Pre-conventional, Conventional, Post-conventional. The theoretical base of morals' level Ilmu al-Akhlaq can be taken from the concept of taqlid (ittiba') and ijtihad which comes from the Ushul Fiqh theory that can be matched with heteronomous and autonomous concepts in the cognitive moral theory which is being the theoretical basis of moral reasoning.
\end{abstract}

Keywords-moral reasoning; Kohlberg's theory; Islamic education perpsective

\section{INTRODUCTION}

Moral education becomes the prospect of life improvement because moral education helps everyone in society to behave and act in harmony with the norms of society. People who have members with high morality have a tendency to be able to create a harmonious order and regularity atmosphere, to present comfort and safety together, and to create justice in the society. On the contrary, the low moral people are often to be the source of troubles, creating noise, anarchism, and becoming the cause of division and chaos in life. The Awareness of the matter causes humanity since Plato's period has strived for moral education. The study of effective moral education also becomes the concern of Western and Muslim scientists.

Moral is an abstract concept. It becomes difficult to measure a person's moral. Therefore, measuring moral is done by examining its dimension such as moral behavior, moral feeling/attitude or moral reasoning/judgment. Because of the complexity of the discussion about moral, then this study is only focused on moral study from the dimension of moral reasoning. The study of moral reasoning will be presented in two perspectives, Western and Islamic. In this study, the writer tries to present the concept of moral reasoning levels that Kohlberg compiled to be juxtaposed with al-Ghazali and other
Muslim scholars (ulama), and also be examined its congruence, in order to discover its similarities and differences.

Moral reasoning is an important dimension because it is considered to have contribution to a person's moral behavior choice. Good moral reasoning skills tend to make a person choose good moral behavior as well. Moreno, for example, explains that the learners' moral reasoning influences their behavior in the classroom, such as a willingness to respect or obey the class rules and communicate politely to the teachers and friends [1]. According to Power, moral reasoning affects how the person believes that certain behavior should be done [2]. Narvaez concludes from various studies that moral reasoning drives moral behavior [3].

Therefore, moral education is implemented to form the learners' moral reasoning so that they have a high level of moral reasoning. In the context of moral education, the teachers are expected to be able to change the learners' moral reasoning level from low to higher levels. Harman, Mason \& Armstrong say that the teachers are required to be able to form new moral belief and new intention as an effort to improve the learners' moral reasoning, to leave the previous beliefs that have been corrected and revised by the education process they have been experienced [4].

The study is intended to explore Islamic treasures on moral reasoning. In Islamic view, education which shapes people's reasoning including the ones related to morality is considered as a wrongdoing. It can be seen from a research by Michele Mangini which concludes that classic Islamic tradition has recognized ethical reasoning. According to Mangini, Islam encourages the use of objectivity from common sense or rationality in determining the right and the wrong, although it still should remain under the framework of submission to Allah [5]. A research by Widigdo confirms this result stating that in Islam someone's ethic is not merely sourced from religious scriptures but also based on autonomy or one's reasoning [6]. These findings assert that Islam promotes the use of people's reasoning in deciding their morality. However, Mangini and Widigdo have not offered a theoretical model of moral development based on Islamic (cognitive) reasoning as this study. 


\section{METHOD}

The research method using literature studies is carried out with systematic drafting techniques. The steps taken, first by conducting a literature study on the reference handbook, journal, and research conducted relating to the purpose of writing articles. Data collection by direct survey and from literature. Sources of data obtained from primary and secondary sources. Primary sources are original data source sources. Secondary sources are taken from other sources that are not obtained from primary sources.

\section{RESULTS AND DISCUSSION}

The present research discusses the problems based on data gained from books, manuscripts, research journals, and other academic documents by experts. It is classified as a library research [7]. The first section explores morality reasoning theory developed by Jean Piaget and Lawrence Kohlberg to represent western tradition. In the second section, the researcher traces down the idea from Islamic theologians such as Al Ghazali that represents Islamic view towards morality. The third part, researcher compares the two ideas to find out their similarities and differences which answer the research questions.

\section{A. Kholberg's Theory of Moral Reasoning}

According to Kohlberg, cognitive approach in moral education represents the concept that is known as moral reasoning [8]. Moral reasoning is the ability of a person to understand rationally (logic) what is good and bad, right and wrong, along with the ability to recognize the implications and consequences of the behavior chosen. A person who has a good moral reasoning, has the basic consideration used in choosing behavior, not only because his choice is profitable or pleasing to him, more than that the consideration of choosing behavior is more based on the principles contained in moral values.

The maturity of thinking about the consideration or moral's reason that becomes the basic for choosing behavior is called the ability of moral reasoning. This meaning is in line with Kohlberg's concept of moral reasoning that is moral judgment. Moral reasoning is also defined as the reasoning process used to form new moral belief and values to be chosen as the most correct or best belief [4].

Kohlberg divides moral reasoning into three levels: the preconventional, conventional and post-conventional [9]. Preconventional is moral reasoning in which a person at this level chooses to have attitude and act based on the consideration that his choice produces pleasure or physical enjoyment. While the Conventional level is characterized by the response of attitude and behavior based on the consideration that it is a provision or rule that is applied. The Post-conventional level is achieved by a person who has attitude and act based on the basic of values or universal principles that have become his worldview.

Kohlberg, for further, details the three levels of moral reasoning into six stages, each level consists of two stages [9].
Pre-conventional consists of: (a) The Punishment and Obedience Orientation, (b) The instrumental Relative Orientation. Conventional consists of (c) The Interpersonal Concordance or Good Boy-Nice Girl Orientation, (d) The Law and Order Orientation. Post-conventional consists of (e) The Social Contract or Legalistic Orientation, (f) The Universal Ethical Principle Orientation. The stages aimed by Kohlberg are a person's mental condition when choosing an action. That mental condition is a reason or judgment in person's mind used for choosing an action. The reason or judgment can change from the reason as well as the first stage to a reason or judgment as well as second stage and so on. The stages of moral development are explained by Kohlberg as follows:

- The Punishment and Obedience Orientation (Orientation of Punishment and Compliance); A person who is at this stage chooses an attitude or action based on a desire to escape from punishment or because of blindly obedience to someone who has power over him. At this stage, the standard of good and bad action is determined by the physical consequences that will be experienced if he doesn't take that good action perceived.

- The Instrumental Relative Orientation (Orientation of necessity Fulfillment); the Consideration of choosing a particular attitude or action due to wants to get pleasure or satisfaction. An action is considered to be good or right if it can give satisfaction for himself and sometimes for others. Sometimes he uses other people to get pleasure. The barter principle (marketplace) often becomes a part of his behavior, for example "he hit me then I hit him too, he gives me a drink so I give him food".

- The Interpersonal Concordance or Good Boy-Nice Girl Orientation (Orientation of Concord or Good People); A person who is at this stage has a characteristic when he chooses an action based on the purpose of being called a good person. He acts according to the expectations of his social environment, whether his family, society or nation. The standard of good or bad action is whether good or bad action according to other people.

- The Law and Order Orientation (Orientation of Order and Law); a person's behavior at this stage is based on the thought of maintaining social order and obeying the law or the applied rules. For someone who is at this stage, having a good behavior is to fulfill obligations, to obey leader, to obey the law and to keep the people in peace.

- The Social Contract or Legalistic Orientation (Orientation of Social Contract); in this stage, a person has a reasoning that the right action is an action that is judged true by the society resulted from an agreement. He realizes that individual truth is relative, so that it is needed an effort to get an agreement together on what is right. He also realizes that the law can be changed with approval together, therefore he holds that if the law blocks humanity, then the law can be changed.

- The Universal Ethical Principle Orientation; The moral 
reasoning which is had by a person at this stage is awareness that the right action is an action which is suitable with what a heart says and universal principles, such as similarity of human beings, respect for human dignity and justice for all people.

TABLE I. MORAL REASONING LEVEL BY KOHLBERG

\begin{tabular}{|c|c|c|}
\hline Pre-convensional & Conventional & Post-Conventional \\
\hline $\begin{array}{l}\text { 1. Doing } \\
\text { something to } \\
\text { avoid } \\
\text { punishment. }\end{array}$ & $\begin{array}{l}\text { 3. Choosing } \\
\text { particular } \\
\text { attitude or } \\
\text { behavior in order } \\
\text { to be respected }\end{array}$ & $\begin{array}{l}\text { 5. Doing Attitude and } \\
\text { behavior based on } \\
\text { assumption that } \\
\text { those are an } \\
\text { obligation }\end{array}$ \\
\hline $\begin{array}{ll}\text { 2. } & \text { Doing } \\
\text { something to } \\
\text { get } \\
\text { repayment }\end{array}$ & $\begin{array}{l}\text { 4. Choosing } \\
\text { attitude or } \\
\text { behavior to keep } \\
\text { social regularity }\end{array}$ & $\begin{array}{l}\text { 6. Taking attitude or } \\
\text { behavior based on } \\
\text { those are in line } \\
\text { with universal } \\
\text { principles } \\
\text { (goodness, justice, } \\
\text { equality, and etc) }\end{array}$ \\
\hline
\end{tabular}

The implication of Kohlberg's view in moral education has become a serious study and provides a specific model of learning. In order to change the learners' moral level from lower to higher, Kohlberg suggests to use moral discussion learning. In the discussion, it is presented a moral story that contains a dilemma (problem) so that learners can express their moral view. The moral view of the learner can be identified by his moral reasoning level by looking at the reasons or considerations used in choosing a response (attitude or behavior) to the problem faced, whether he is at a preconventional, conventional or post-conventional level.

The learning process which uses moral dilemma discussion can stimulate the change of learners' moral reasoning level. Faced on the moral problems of learners, it often experiences the process of disequilibrium, a condition in which he is in doubt due to the new knowledge / moral values absorbed which are different from the old knowledge / moral values that have been believed during this time. This doubt and confusion will become a source of discomfort to the learners that require them to find the most appropriate solution to hold on to. The one (and be expected) solution is the moving of learners' belief from old to new moral values based on the consideration or reason in accordance with higher levels of moral reasoning. When the learners have found a new belief, it means that a new equilibrium condition has been present at him, so that he has steadiness in carrying out his moral choice. Therefore, the learning process that presents the condition of disequilibriumequilibrium is able to increase the moral level of learner [10].

\section{B. The Cognitive Developmental Theory as The Moral Reasoning Base}

The establishment of learners' moral reasoning refers to the Cognitive Developmental theory pioneered by Piaget and developed by Kohlberg. To distinguish between Cognitive Developmental Theory and other moral theory of educational psychology, Hoffman describes as follows: (a) Social-Learning Theory examines moral establishment by taking moral behavior as the object. The Method of moral establishment according to this theory is done by accustoming moral behavior accompanied by reward, punishment and imitation. (b) Cognitive Developmental Theory examines person's moral development in terms of reasoning (moral reasoning). Moral establishment can be made when aspects of reasoning are also developed, such as perspective-taking, reciprocity, cognitive dis-equilibrium, progressive construction, and co-construction [11].

Emotional-Motivational Development Theory has the view that to establish an effective moral can be done by developing emotional aspect such as empathy, sympathy and caring. So it can be concluded that the first theory takes moral-action or moral-behavior as the object of reasoning, the second theory takes the object of moral-reason or moral-cognition, and the third theory is carrying mission in the field of moral-feeling or moral-affect. These three moral theories are in line with the division of moral studies (characters) according to Lickona, which states that the moral field covers knowing, feeling and behavior [12].

The Development of cognitive moral theory is, starting from Piaget's intellectual activity that investigates the influence of individual subjective values on moral behavior. This effort is different from previous scientists focused on observable behavior [13]. In a book entitled The Moral Judgment of the Child published, Piaget identifies two types of moral reasoning (part of subjective value) which are had by the object of his investigation; heteronomous morality and autonomous morality [14]. The children who are six to twelve years old, is generally still a heteronomy which is their moral attitude is controlled by an authority outside of themselves or an adult, such as their parents or teacher. Whereas the children whose age is upper than those, tend to have autonomy, that is a moral attitude derived from their own reasoning which has been constructed from the struggle of moral problems they faced.

Piaget's intellectual activity in the field of moral development theory is continued by Kohlberg who examines moral judgment development more depthly. It is acknowledged by Kohlberg who stated [13]:

My own involvement in this research history dates from 1955, when I commenced my dissertation [8], with the intent of carrying forward into adolescence Piaget's pionering investigation of the moral development of moral judgment in children. In studying moral development in adolescence, I decided to use Piagets's assumstions and method.

The theories developed by Kohlberg are assumed to continue the theories developed by Piaget, one of them is Piaget's theory which states that a person's moral development can be grouped into heteronomy and autonomy, it is detailed by Kohlberg with moral reasoning theory (moral judgment).

According to Kohlberg, heteronomus morality covers preconventional and conventional levels, whereas autonomous morality is achieved by person who is experiencing post- 
conventional moral development level. Therefore, these two figures are considered as the founders of cognitive moral theory, because they put the basic foundation in the moral development theory based on the way of cognitive working.

In Piaget's and Kholberg's opinion, to know a person's moral maturity cannot rely on the knowledge of moral behavior. Therefore, their concentration in moral studies is focused on the domain of moral reasoning or moral judgment, not on moral action [15]. The domain of moral reasoning is cognitive domain. Moral reasoning becomes the focus of study because it is responsible for the choice of person's moral behavior. This study of moral reasoning is expected to be able to help the work of moral maturity improvement. This view is the basis for the development of cognitive moral theory.

To know the alteration process of a person's reasoning, it is necessary to see how reason or cognitive works. According to Piaget, the cognitive learning process consists of three stages, they are: assimilation, accommodation and equilibration [16]. The first stage (assimilation) is the learning stage in which new knowledge is included into the mental structure of learners so that their knowledge bank becomes increased or better. The second stage (accommodation) is the learning stage in which the learners' mental is forced to adapt the new knowledge they received and in this process the learners have experience in mental imbalance (disequilibrium) due to the presence of new knowledge in conflict with old knowledge which is the first time had on the learners' selves. The third stage (equilibration) is the stage of mental balance that grows after the mental conflict can be overcome [17][18].

The result of the mental process in cognitive learning above is the mental condition of learners who have received and believed that the knowledge they have accommodated is true and they commit to hold on firmly to the knowledge. This mental condition is called equilibrium.

If learning process can't present the three stages (process) of learning as above, then cognitive learning will become less optimal. This learning is less able to absorb the desired value or attitude to the learners. Therefore, learning must use a model, strategy or method that can facilitate the three stages (processes) of learning to take place, especially equilibration. Learning should be able to stir the mind (mental-state) of learners so that it can make them having experience disequilibrium condition (mental imbalance). This situation encourages learners to find answer that can restore their mental condition to the new equilibrium.

\section{Moral Reasoning Theory base on Islamic Education Perspecteive}

The term of moral reasoning has not yet known in Islamic treasury, nevertheless, the writer believes that the substance and level of moral reasoning as is arranged by Kohlberg has been the first concern of al-Ghazali and other morals' scholars. Therefore, in this study the writer tries to present the concept of moral reasoning levels by Kohlberg and al-Ghazali also other moslem scholars, then it will be examined the congruence so it can be found the similarities and differences.

This moral reasoning theory, is not strange in the perspective of akhlak-tasawuf theory. Although it is scientifically untested, it can rationally be compared between the similarity of moral reasoning level theory and maqamat tasawuf theory. Maqamat here means awam, khawas, and khawas al-khawas. The similarity comes from the point of view of a chosen behavior, awam chooses not to steal because he wants to avoid the misery in this world now and afterlife (the punishment of handscut or hell torture), khawas and khawas al-khawas choose not to steal, but it's not because of hoping heaven pleasure or avoid hell torture, it's because of higher judgment, that is to get ridla or love from the Almighty. The similarity is assuming moral reason as the basic of moral judgment. Of course, there is a difference in terms of the standard of moral, Kohlberg's moral reasoning is based on moral truth which points to rationality, while akhlak reasoning is based on religious truth.

TABLE II. THE CONCEPT OF AKHLAK’S LEVEL

\begin{tabular}{|l|l|l|}
\hline \multicolumn{1}{|c|}{ Awam } & \multicolumn{1}{|c|}{ Khawas } & \multicolumn{1}{c|}{ Khawasul Khawas } \\
\hline $\begin{array}{l}\text { Doing worship/ } \\
\text { behavior based on }\end{array}$ & $\begin{array}{l}\text { doing worship/ } \\
\text { behavior in order to }\end{array}$ & $\begin{array}{l}\text { Doing worship/behavior } \\
\text { because of depth }\end{array}$ \\
feeling of afraid to & be loyal person for & awareness that \\
allah's torture & Allah, and by his & everything in this world \\
reward from Him & loyality, then he will & is just Allah's and only \\
& get something from & Allah is the Greatest \\
& Allah SWT & one \\
\hline
\end{tabular}

Some examples of moral reasoning in the activity of worship or behavior which follow the level of morals' level (awam, khawas and khawasul khawas) can be explained as follows:

- Shiam (fasting); awam person fasts to avoid himself from those which can break his fasting such as eating, drinking and intercourse, while khawas person refrain from doing something that break his fasting reward, as well as awam's fasting is also done by preventing themselves from doing immoral, such as looking at person's opposite sex, whereas khawas al-khawas person do what awam and khawas do also prevent themselves from doing something which is makruh and not useful [19].

- Taubah (repentance); for awam person, repent means regret and promise not to do the sin that has been done, whereas for khawas person, repent is regret and promise not to be careless from remembering Allah SWT in every his breath and of course prevents himself from doing sin. ${ }^{20}$ Awam person repents for fear of Allah's torture, while khawas person repents for feeling ashamed to Allah [18].

- Zuhud (ascetic); the behavior of avoiding or abandoning world pleasures can also be grouped into three kinds. For awam person, zuhud is to move away from being worldly in order to be avoided from the punishment of afterlife, khawas person behaved zuhud to expect the reward afterlife, and khawas al-khawas person behaved zuhud 
only because of Allah's love, not for fear of His torture or expect His heaven[20].

TABLE III. THE PERSPECTIVE BEHAVIOR/WORSHIP OF AWAM, KHAWAS, KHAWASUL KHAWAS

\begin{tabular}{|c|c|c|c|}
\hline $\begin{array}{l}\text { Level Behavior/ } \\
\text { Worship }\end{array}$ & Awam & Khawas & $\begin{array}{c}\text { Khawas a- } \\
\text { lkhawas }\end{array}$ \\
\hline Shiam/Fasting & $\begin{array}{l}\text { Refraining } \\
\text { himself from } \\
\text { eating, drinking, } \\
\text { and having } \\
\text { intercourse }\end{array}$ & $\begin{array}{l}\text { besides of } \\
\text { preventing what } \\
\text { awam's doing, } \\
\text { Khawas person } \\
\text { also refrains } \\
\text { himself to do } \\
\text { immoral by his } \\
\text { part of body }\end{array}$ & $\begin{array}{l}\text { Besides of } \\
\text { doing } \\
\text { khawas } \\
\text { behavior, he } \\
\text { also } \\
\text { prevents } \\
\text { himself to } \\
\text { do } \\
\text { something } \\
\text { makruh or } \\
\text { useless. }\end{array}$ \\
\hline Taubah/Repentance & $\begin{array}{l}\text { repenting from } \\
\text { sin (being afraid } \\
\text { of Allah's torture }\end{array}$ & $\begin{array}{l}\text { repenting from } \\
\text { being careless } \\
\text { (being ashamed } \\
\text { to Allah) }\end{array}$ & \\
\hline Zuhud/Ascetic & $\begin{array}{l}\text { Doing zuhud } \\
\text { because of afraid } \\
\text { to get the } \\
\text { punishment } \\
\text { afterlife }\end{array}$ & $\begin{array}{l}\text { doing zuhud is } \\
\text { for hoping the } \\
\text { reward afterlife }\end{array}$ & $\begin{array}{l}\text { Doing } \\
\text { zuhud is } \\
\text { only for } \\
\text { loving } \\
\text { Allah } \\
\end{array}$ \\
\hline
\end{tabular}

The ability of moral reasoning relates to moral maturity, the higher the level of person's moral reasoning, the more mature person's moral behavior. In other words, it's more morally the behavior based on post-conventional than conventional reasoning, and more morally behavior based on conventional reasoning than the pre-conventional reasoning. Even if preconventional is a low moral level, but it has been included in a moral criterion, not a pramoral. So, the challenge of moral or morals learning is how to improve the moral reasoning of learners in order to reach a higher level. This is in line with what the cognitive moral theory recommended, that is the chosen moral learning program must be able to increase the learners' capacity in terms of reasoning skill and good judgment [13].

The main issue is how to change person's moral reasoning level from a pre-conventional level to conventional or postconventional level. In the context of morals is how to change the level of morals' reasoning from awam to khawas or khawasul khawas. In this case, Kohlberg has examined the truth of cognitive theory about the process of reasoning (cognitive), one of them is disequilibirum. Kohlberg's research proves that person's moral reasoning can be increased by moral learning which is capable to bring up disequilibrium [10]. Thus, cognitive moral learning that presents the condition of disequlibrium can change the level of learners' moral reasoning.

Besides akhlaq level can use the concept of awam, khawas, khawas al-khawas, it also can use dimension of Islamic teachings consisting of aqidah-syariah-akhlaq or iman-islamihsan. In Islamic discourses, it often happen a debate between the truth of behavior based on syari'ah (Islamic) and the truth of behavior based on akhlaq (ihsan).
It's not a few that the end of debate resulted in the conclusion that the truth of morals (ihsan) is believed to be higher than the truth of syar'i (figh). The degree of syari'ah behavior value is considered lower than the degree of haqiqat/makrifat (akhlak) behavioral value. This proposition is reinforced and confirmed by some of the following examples of Islamic teachings; (1) it is recommended to stop praying to help the drowned person, (2) it is recommended to give water to a thirsty dog than used for wudlu. Doing pray and wudlu are a syari'ah obligation while helping drowned person and thirsty dog are an akhlaq demands. From these two examples of teachings, it can be formulated an assumption, that Islam is more defending akhlaq than syari'ah.

This view is also reinforced in Qur'an (8: 65-82) which tells the meeting of Prophet Musa with Prophet Hidir. ${ }^{25}$ In this story Prophet Musa was ordered to study with Prophet Hidir. In these stories, there are higher moral values to be the basic of thinking about moral truth. The perspective of judging the right or wrong of a behavior is on awam's perspective (society in general). In these stories, there is a value conflict in which awam's perspective (syariat) is forced to deal with khawas' perspective (haqiqat). For example, Musa's point of view represents awam's view (syariat) which states that killing a person is wrong and sin, it's contrary to the Hidir's point of view (khawas/haqiqat) who assumes that the murder of person in this case is the correct behavior for saving people from the destruction caused by the person's actions.

The view that the akhlaq level is higher than syariah, is in line with the thought of Hamka and Harun Nasuiton that put akhlaq's dimension after aqidah, not after syariah (aqidah, akhlak, syariah). The position of morals in Islamic teachings according to Nasution is in the second position after tauhid. ${ }^{26}$ From the three aspects of Islamic teachings; aqidah, syariah and akhlak, Nasution puts akhlak after aqidah. Of course this opinion is different from the view of moslem scholars in general who believe morals is the result of aqidah and syari'ah, so they put akhlaq in the third position [21].

Nasution's opinion is not different from Hamka. According to Hamka, the position of morals in the structure of Islamic teachings, can be described as follows [22]:

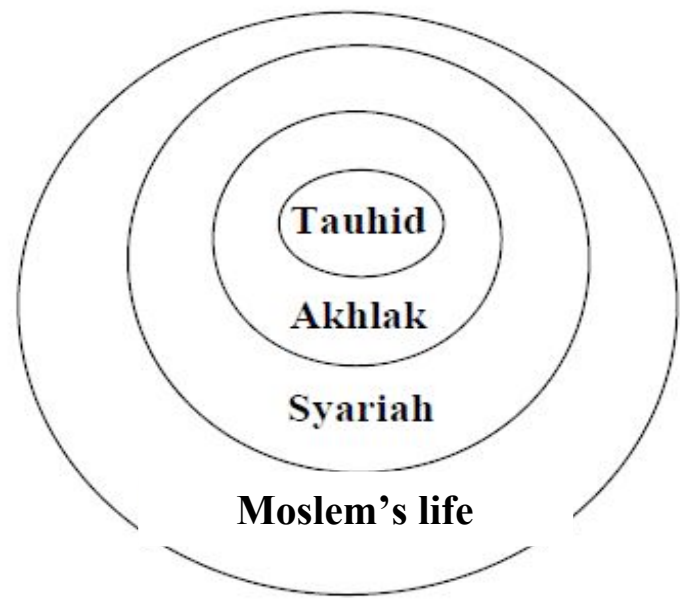

Fig. 1. The Structure of Islamic Teachings [22] 
In the figure, akhlaq as Islamic teachings occupies second position after the core teachings, namely tauhid teachings. It means that morals in Islam should always be imbued by tauhid teachings. Meanwhile, syari'ah as islamic teachings gets the third position from tauhid teachings and after akhlak (ethics). It means that syari'ah in Islam must always be imbued by tauhid and akhlaq. Syari'ah and its implementation may not come out of the design and teachings of tauhid and morals.

Thus, in the study of Islamic science (morals) can actually recognize the levels of moral reasoning. These levels can refer to the concept of tasawuf (awam, khawas, khawasul khawas), or refer to the dimensions of Islamic teachings (syariat-akhlak / haqiqat), which is juxtaposed with the pre-conventional, conventional and post-conventional.

Related to the theoretical base of moral reasoning, as described above, Piaget gives an explanation that the basic of person's reasoning can be categorized into two things; the reasoning that depends on other people (heteronomous) and autonomous reasoning. In morals science, the theoretical base of moral levels can use ushul fiqh theory which divides the independence of person's thinking into two categories, taqlid and ijtihad. The concept of taqlid and ijtihad can be equated with heteronomous and autonomous in cognitive moral theory.

TABLE IV. THE COMPARISON BETWEEN WESTERN AND ISLAMIC MORAL THEORY

\begin{tabular}{|l|l|l|}
\hline Perspective & \multicolumn{1}{|c|}{ Theoretical base } & \multicolumn{1}{c|}{ Moral's level } \\
\hline Kohlberg at al & $\begin{array}{l}\text { Cognitive moral } \\
\text { theory } \\
\text { (heteronomous- } \\
\text { autonomous) }\end{array}$ & $\begin{array}{l}\text { Pre-conventional } \\
\text { Conventional } \\
\text { Post-conventional }\end{array}$ \\
\hline $\begin{array}{l}\text { Al-Ghazali at } \\
\text { al }\end{array}$ & $\begin{array}{l}\text { Ushul Fiqh theory } \\
\text { (taqlid/ittiba'-ijtihad) }\end{array}$ & $\begin{array}{l}\text { Awam (syariat) } \\
\text { Khawas (akhlak/haqiqat) } \\
\text { Khawas al-Khawas } \\
\text { (akhlak/haqiqat) }\end{array}$ \\
\hline
\end{tabular}

This is reinforced by the description of al-Ghazali in Ihya Ulumuddin on Chapter Qalbun using taqlid theme to be used for giving attribute of awam's faith. Al-Ghazali states that awam's faith is marked by taqlid (al-Ghazali). From this thought, it can be explained that the concept of taqlid according to the writer is the equivalence of heteronomy concept, which is not only used in the fiqh discourses but also used in the field of akhlaq as well as on Al-Ghazali's study. The way of imitated thinking with other people becomes the basic for awam's level, and of course for khawas or khawas al-khawas' level, using the ability of thinking is more independently (ijtihad) in doing morals [23].

From descriptions, we can find the basic similarity of Western and Islamic theories in the field of moral reasoning. For a person who is at a pre-conventional level, his moral behavior is more heteronomous or likely to be influenced by other people or something outside himself, whereas a person who is at conventional and post-conventional levels is more autonomous or independent. Similar to moral reasoning in Islam, awam's level in moral theory tends to be taqlidi (heteronomous), that is the moral behavior follows other people who are assumed to be credible, while the level of khawas and khawas al-khawas is characterized by its independence in determining the good or bad moral behavior (ijtihadi or autonomous).

\section{CONCLUSION}

The encounter of Ilmu al-Akhlaq with cognitive theory and moral reasoning actually is not strange, even it can be said to precede moral reasoning in the treasury of Western ethics. The concept of moral level in Islam formulated by al-Ghazali and other moslem scholars (awam, khawas, khawas al-khawas), has congruences with the theory of Kohlberg's Moral level (pre-conventional, conventional, post-conventional). The difference is Islamic moral reasoning has not been formulated quantitatively as Western moral reasoning, because Moslems experience the left behind-civilization before entering the modern world (positivistic), while Western moral reasoning born in modern period is helped by quantitative positivist scientific tools. Piaget-Kohlberg's moral reasoning has an effective usage because it is able to be formulated a technology that applies those theories in people's life as its derivative products in the form of moral reasoning tests, strategies and moral enhancement models.

Unfortunately, the thought of moral reasoning in Islamic perspective has not been formulated operational technically (applied science) so that it cannot be used practically, it's different from the thought of moral reasoning that has been studied scientifically-quantitatively in order to produce moral measurement instruments that can be used in educational activities. Some standard moral reasoning tools or instruments are the Moral Judgment Interview (MJI) developed by Lawrence Kohlberg, the Defining Issues Test (DIT) compiled by James Rest, and the Moral Judgment Test (MJT) designed by George Lind. By using this measurement instrument of moral reasoning, teachers will easily know the moral development of learners, and also can ensure the success or failure of moral education which is implemented.

The study of the measurement science of moral reasoning has also been completed by the study of learning methods / strategies that can increase or change moral reasoning from lower to higher levels; selected by Moral Dilemma Discussion (MDD), Value Clarification Techniques (VCT), or Problem Based Learning (PBL). MDD is a learning method that presents a dilemma story (problematic) to be discussed the best/right one behavioral choice with learners' reason. While VCT is a learning technique that presents contradictory moral values to be overtaken its strengths and weaknesses so it can be selected the most superior moral values. It's contrary with MDD and VCT, PBL is a strategy that provides real problems to be scientifically studied the solutions that can be used to solve moral problems. Some of methods or strategies above may the cognitive learning process along with the stages which are able to be facilitated so that the moral reasoning of learners can be improved.

The challenge in Islamic education is, Do Muslim scientists have the interest and ability in translating the treasure of morals' science which is rich into the applied sciences that are practical and effective in helping the progress of Islamic 
education, especially the development of the learners' moral reasoning?

\section{REFERENCES}

[1] R. Moreno, Educational Psychology. New Jersey: John Wiley \& Sons, Inc., 2010.

[2] F. K. . et al Power, Moral Education: A Handbook, Volumes 1\&2. Westport: Praeger, 2008.

[3] D. Narvaez, "Human Flourishing and Moral Development: Cognitive and Neurobiological Perspectives of Virtue Development," in Handbook of moral and character education, 2008, p. 310.

[4] J. M. et al Doris, The Moral Psychology Handbook. New York: Oxford University Press, 2010.

[5] M. Mangini, "Rationality and Ethics between Western and Islamic Tradition," Religions, vol. 9, no. 10, p. 302, 2018.

[6] M. S. A. Widigdo, "Human Agency in Islamic Moral Reasoning," Kanz Philos., vol. 4, no. 1, pp. 15-27, 2014.

[7] M. W. George, The Elements of Library Research. New Jersey: Princeton University Press, 2008

[8] L. Kohlberg, "The Child as a Moral Philosopher," Psychol. Today, vol. 2, no. 4, pp. 24-30, 1968

[9] L. Kohlberg and R. H. Hersch, "Moral Development: A Review of the Theory," Moral Dev., vol. 16, no. 2, pp. 53-59, 1977.

[10] R. R. Newton, "Kohlberg: Implications for high school programs," Living Light, vol. 15, no. 2, pp. 231-239, 1978
[11] M. L. Hoffman, Empathy and Moral Development: Implications for Caring and Justice. Cambridge University Press, 2007.

[12] T. Lickona, "The Return of Character Education," in Taking Side: Clashing Views on Controversial Educational Issues, Iowa, USA: McGraw-Hill/Dushkin, 2005, pp. 310-316.

[13] J. Rest, Development in judging moral issues. Minneapolis: University of Minnesota Press, 1979.

[14] J. Piaget, The Moral Judgment of the Child. Illinois: The Free Press, 1965.

[15] M. Duska, R., \& Whelan, Moral development: A Guide to Piaget and Kohlberg. 1975.

[16] J. Piaget, "Problems of Equilibration," Top. Cogn. Dev., pp. 3-13, 1977.

[17] A. Pritchard, Ways of Learning. New York: Routledge, 2009.

[18] B. R. Hergenhahn and M. H. Olson, An Introduction to Theories of Learning, Fifth Edit. New Jersey: Prentice Hall, 1997.

[19] A. H. Al-Ghazali, Mukhtashar Ihya`Ulumuddin. Jakarta, Indonesia: Pustaka Amani, 1995.

[20] H. Tualeka, Akhlak Tasawuf. Surabaya: IAIN Sunan Ampel Press, 2012.

[21] H. Nasution, Islam Rasional. Bandung, Indonesia: Mizan, 1995.

[22] Hamka, Pandangan Hidup Muslim. Jakarta, Indonesia: Bulan Bintang, 1992.

[23] I. Al-Ghazali, Ihya Ulumuddin, Jilid III. Medan: Percetakan Imballo, 1963. 